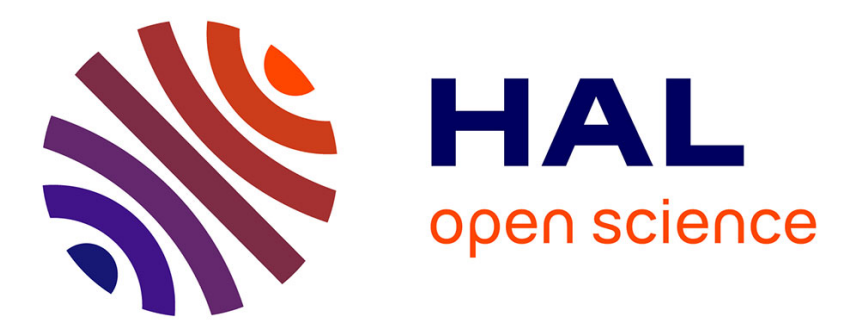

\title{
Modelling temperature-dependent bionomics of Bemisia tabaci (Q-biotype)
}

\author{
Olivier Bonato, Amandine Lurette, Claire Vidal, J. Fargues
}

\section{To cite this version:}

Olivier Bonato, Amandine Lurette, Claire Vidal, J. Fargues. Modelling temperature-dependent bionomics of Bemisia tabaci (Q-biotype). Physiological Entomology, 2007, 32 (1), pp.50-55. 10.1111/j.1365-3032.2006.00540.x . ird-01224737

\section{HAL Id: ird-01224737 https://hal.ird.fr/ird-01224737}

Submitted on 5 Nov 2015

HAL is a multi-disciplinary open access archive for the deposit and dissemination of scientific research documents, whether they are published or not. The documents may come from teaching and research institutions in France or abroad, or from public or private research centers.
L'archive ouverte pluridisciplinaire HAL, est destinée au dépôt et à la diffusion de documents scientifiques de niveau recherche, publiés ou non, émanant des établissements d'enseignement et de recherche français ou étrangers, des laboratoires publics ou privés. 


\section{Modelling temperature-dependent bionomics of Bemisia tabaci (Q-}

2 biotype)

3

4 OLIVIER BONATO ${ }^{1}$, AMANDINE LURETTE, CLAIRE VIDAL and JACQUES

5 FARGUES

6 IRD-INRA Centre for Biology and Management of Populations (CBGP), Montferrier /

$7 \quad$ Lez cedex, France

8

9 Abstract

10 The influence of temperature $\left(17,21,25,30\right.$ and $\left.35^{\circ} \mathrm{C}\right)$ on life history traits of a Q-

11 biotype Bemisia tabaci population on tomato is studied. Temperature dependent

12 relationships are characterized for immature developmental rate, immature survival,

13 fecundity, longevity and intrinsic rate of increase. Development time vary from 20

14 days at $30^{\circ} \mathrm{C}$ to 56 days at $17^{\circ} \mathrm{C}$ and the lowest thermal threshold is estimated at

$1510.2^{\circ} \mathrm{C}$. The optimal temperature for immature development is $32.5^{\circ} \mathrm{C}$. Total

16 fecundity (eggs per female) ranges from 105.3 (at $21^{\circ} \mathrm{C}$ ) to 41 (at $35^{\circ} \mathrm{C}$ ). The

17 longevity decreases with temperature increase. The intrinsic rate of increase ranges

18 from 0.0450 (at $17^{\circ} \mathrm{C}$ ) to 0.123 (at $30^{\circ} \mathrm{C}$ ). The functional relationships between

19 temperature and life-history parameters are used to evaluate the effect of temperature

20 on the population dynamics. Such mathematical relationships could provide a basis

21 for future development of population models.

23 Key words

\footnotetext{
${ }^{1}$ Correspondence : Dr Olivier Bonato, IRD-CBGP, CS 30 016, 34988 Montferrier/Lez, France. Tel. : +3346799623306; fax : +3346799623345 ; e-mail : bonato@mpl.ird.fr
} 
24 Temperature, bionomics, Bemisia tabaci, Q biotype, modelling

\section{Introduction}

28 The sweetpotato whitefly, Bemisia tabaci (Gennadius) (Hemiptera: Aleyrodidae) is

29 one of the most serious agricultural pest on tomato Lycopersicum esculentum (Mill)

30 and other horticultural crops in tropical and subtropical temperature regions world31 wide. Damage may be caused directly by feeding on phloem or deposition of

32 honeydew, or indirectly by transmitting different types of plant viruses, such as the

33 tomato yellow leaf curl virus (Oliveira et al., 2001), to a wide range of vegetable

34 crops. The potential of $B$. tabaci to develop resistance in response to intensive use of

35 pesticides has led to studies on integrated pest management strategies in which

36 biological control plays a central role, and significant advances have been made in

37 developing and implementing management systems (Gerling \& Mayer, 1996;

38 Naranjo, 2001). As a general rule, any pest management programme should be based

39 on adequate knowledge of the main factors responsible for changes in population

40 dynamics. Life history parameters estimated under different biotic or abiotic

41 conditions provide the basic tools for among others, understanding changes in the

42 status of pest species (Poole, 1974; Dempster, 1975; Krebs, 1978; Southwood, 1978).

43 Because B. tabaci is a poikilothermic organism i.e. temperature influences the life

44 table components, it is important to take this factor into consideration in explaining

45 population ecology. A review by Drost et al. (1998) reported that biological

46 parameters of $B$. tabaci have been characterized for different temperatures, host

47 plants and biotypes. Among this vast amount of literature, the most complete work is

48 probably that of Wang \& Tsai (1996) concerning B-biotype reared on aubergine. 
49 The Q-biotype of B. tabaci was first characterized in samples collected in the south

50 of Spain and Portugal (Guiro et al., 1997). Successive surveys showed that this

51 biotype is also present in Tunisia (Chermitti et al., 1997), Morocco (Monci et al.,

52 2000), Egypt (De Barro et al., 2000), Israel (Horowitz et al. 2003) and southern Italy

53 (Demichelis et al., 2000; Simón et al., 2003). Because of its high degree of

54 polyphagy and its ability to transmit a relatively wide range of plant viruses, the Q-

55 biotype is considered as a particularly dangerous biotype (Muñiz, 2000; Navas-

56 Castillo et al., 2000). In spite of the wide distribution of the Q-biotype in the

57 Mediterranean basin, no complete published work is available currently on its life-

58 history parameters in relation to temperature when reared on tomato. The aim of the

59 present study was to characterize and analyze functional relationships between

60 temperature and life-history parameters and to evaluate the effect of temperature on

61 the dynamics of Q-biotype populations.

62

\section{Materials and methods}

65 Whitefly source and host plant production

67 In 2002, founders of Bemisia tabaci of the Q biotype were collected from a 68 greenhouse of tomato crop located in Alenya in the South of France $\left(42^{\circ} 38^{\prime} \mathrm{N}\right.$; $\left.692^{\circ} 58^{\prime} \mathrm{E}\right)$. The stock colony was reared and maintained on tomato plants of the cv

70 Hilario ${ }^{\circledR}$ (Royal Sluis, Enkhuizen, The Netherlands) in plastic cages placed in 71 climatic chambers at $25 \pm 1^{\circ} \mathrm{C}$, and $60 \pm 5 \% \mathrm{RH}$. Experiments were carried out using 72 progeny after more than 3 generations on Hilario. 
76 Young adults of $B$. tabaci (150 pairs: male and female) were placed in cubic 77 screened cages $(50 \times 50 \times 50 \mathrm{~cm})$ each containing a young potted tomato plant. The 78 cages containing adults were maintained in a growth chamber at $25 \pm 1{ }^{\circ} \mathrm{C}, 60 \pm 5 \%$ $79 \mathrm{RH}$ in a LD 14:10 h photocycle. Whitefly adults were given $3 \mathrm{~h}$ to lay eggs. The 80 adults were then removed, leaves were observed under a stereo-microscope at $36 \mathrm{X}$ 81 magnification. Two eggs on the abaxial surface of 5 leaves were kept and excess 82 eggs were killed using an insect pin. Plants were then placed in growth chambers set 83 at 5 constant temperatures: $17,21,25,30$ and $35^{\circ} \mathrm{C}$ with six replicates. Once the eggs 84 hatched and the crawlers fixed on the leaf, young nymphs were identified 85 individually. Each nymph was observed daily until adult emergence, and the 86 transition from one stage to another was noted. Differences between developmental

87 times were tested by one-way ANOVA and means were separated by Newman88 Keuls test $(\alpha=0.05)$. Statistical analyses were performed using X1Stat 7.1 89 (Addinsoft). The influence of temperature $(T)$ on developmental rate was described 90 by the model proposed by Logan et al. (1976):

$\left.91 D R=p 1 \times\left[\exp (p 2 \times(T-T i))-\exp \left(p 2 \times(T m-T i)-\left(\frac{1}{p 3}\right) \times(T m-T)\right)\right]\right\rfloor$

92 where $D R$ is the development rate which is the reciprocal of development time, $T i$ is

93 the lower temperature tested and $T m$ is the upper threshold derived from the 94 observations. The parameters, $p 1, p 2$ and $p 3$ were estimated by regression. The 95 lowest thermal threshold for development $(L T T)$ was calculated by the ratio: $L T T=$ $96 a / b, a$ and $b$ were determined by linear regression of the equation $D R=a+b T$, for temperature $(T)$ interval over which the relation was linear. 
98 Differences between survival rates were tested using $\chi^{2}$ test $(\alpha=0.05)$. The

99 relationship between temperature $(T)$ and immature survival rate was described by

100 the Curry \& Feldman (1987) model:

101

102

103

104

$$
S I=\frac{\left((T+273) \times \exp \left(p 1-\left(\frac{p 2}{(T+273)}\right)\right)\right)}{\left(1+\exp \left(p 3+\left(\frac{p 4}{(T+273)}\right)\right)+\exp \left(p 5-\left(\frac{p 6}{(T+273)}\right)\right)\right)}
$$

105

106 Where $S I$ is survival of immatures, $T$ is temperature in ${ }^{\circ} \mathrm{C}$, and $p 1$ to $p 6$ are regression coefficients.

108

109 Reproductive capacity and female longevity

110

111 One newly emerged $(<24 \mathrm{~h})$ female and two males were placed in a clip-cage on the

112 abaxial surface of new leaflets. For each temperature tested, 30 clip-cages were kept

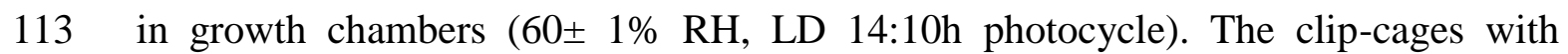

114 insects were moved to new leaves daily and the number of eggs laid per female was

115 counted until death of the female. Differences in fecundity and female longevity

116 were compared with ANOVA followed by a Newman-Keuls tests $(\alpha=0.05)$.

117 Exponential functions were used to describe the influence of temperature on total

118 fecundity and longevity.

119 Fecundity:

$$
E N=p 1 \times\left[\left(T^{p 2}\right) \times \exp (p 3 \times T)\right]
$$


122 Where $E N$ is total number of eggs laid per female; $T$ is temperature in ${ }^{\circ} \mathrm{C}$; and $p l$,

$123 p 2, p 3$ are regression coefficients.

124

125 Longevity:

126

$$
L=\exp [p 1+p 2 \times T]
$$

127

128 Where $L$ is longevity per female in days; $T$ is temperature in ${ }^{\circ} \mathrm{C}$; and $p 1, p 2$ : are

129 regression coefficients.

130

131 Demographic parameters

132

133 The net reproductive rate $\left(\mathrm{R}_{0}\right)$, the mean generation time $(\mathrm{G})$, the intrinsic rate of

134 natural increase $\left(r_{m}\right)$ and the finite rate of increase $(\lambda)$ were determined using the

135 program developed by Hulting et al. (1990) in which the parameters are calculated

136 using the method recommended by Birch (1948). The program, based on Jacknife's

137 procedures, gives a variance and hence a standard error to each parameter calculated

138 enabling statistical comparison of values (Meyer, 1986). The relationship between $r_{m}$

139 and temperature was also described using the Logan et al. (1976) model (see above).

\section{$141 \quad$ Results}

143 Development of immatures 
145 B. tabaci required 56 days at $17^{\circ} \mathrm{C}$ to complete its development from egg to adult,

146 but only 20 days at $35^{\circ} \mathrm{C}$ (Table 1 ). Between 17 and $30^{\circ} \mathrm{C}$, the developmental time

147 was negatively correlated with temperature, but no significant difference was found

148 between 30 and $35^{\circ} \mathrm{C}(P>0.05)$. Values of Logan equation parameters were $p 1=$ $1490.0115, p 2=0.0921, p 3=0.3133\left(R^{2}=0.92, P<0.01\right)$. Between 17 and $30^{\circ} \mathrm{C}$, the

150 relation was linear and the $L T T$ was estimated at $10.2^{\circ} \mathrm{C}$ (Fig. 1). The optimal

151 temperature for development, calculated from the derivative Logan equation, was $15232.5^{\circ} \mathrm{C}$.

153 Survival rates at 21,25 and $30^{\circ} \mathrm{C}$ (Table 2) were not significantly different $154\left(\chi \mathrm{w}^{2}=0.695, P=0.707\right)$ even if the highest percentage was measured at $25^{\circ} \mathrm{C}$.

155 Temperature of $17^{\circ} \mathrm{C}$ had the greatest effect on immature development especially in 156 the $4^{\text {th }}$ stadium. The curve obtained by fitting the Curry \& Feldman model to the data $(p 1=-6.55, p 2=-200.18, p 3=-2986.08, p 4=865870, p 5=1353.19, p 6=6417118$, $\left.R^{2}=0.99, P<0.01\right)$ described the influence of temperature very well and indicated that

15917 and $35^{\circ} \mathrm{C}$ were close to the lower and upper thermal limits, respectively (Fig. 2).

Longevity and reproductive capacity of females

163 Temperature had a significant effect on the fecundity and longevity of females. 164 Longevity was negatively correlated with temperature. The longest life was recorded 165 at $17^{\circ} \mathrm{C}$ and the shortest at $35^{\circ} \mathrm{C}$ (Table 3). The pre-oviposition period was very short 166 (less than 24h) for almost all females tested and oviposition period was close to 167 longevity for the 5 temperatures tested. The relation between temperature and female 168 longevity (Fig. 3) was very well described by the exponential function $(p l=5.02$, $\left.169 p 2=-0.079, R^{2}=0.99, P<0.01\right)$. 
170 Except for $17^{\circ} \mathrm{C}$, fecundity followed the same trend as longevity, i. e., was negatively

171 correlated with temperature. Figure 4 shows the influence of temperature on 172 fecundity $\left(p 1=9.9 \mathrm{e}-11, p 2=12.8, p 3=0.54, R^{2}=0.89, P<0.01\right)$. Our results showed

173 that optimal fecundity was obtained from temperatures ranging between 21 and

$17425^{\circ} \mathrm{C}$. The sex-ratio calculated for each treatment was not significantly different than

$17550 \%(P>0.05)$.

176

177

Demographic parameters

178

179 Parameters were calculated with the sex-ratio of $B$. tabaci set to 0.5 . At the five

180 temperatures tested, the highest rate of increase $\left(\mathrm{r}_{\mathrm{m}}\right)$ was obtained at $30^{\circ} \mathrm{C}$ and the 181 lowest at $17^{\circ} \mathrm{C}$ (Table 4). At 25,30 and $35^{\circ} \mathrm{C}$, the rates of increase were not 182 significantly different $(P>0.05)$. The net reproductive rate was lower at $17^{\circ} \mathrm{C}$ and $18335^{\circ} \mathrm{C}$ indicating the proximity of lower and upper thermal thresholds, respectively.

184 The curve (Fig.5) obtained by fitting the Logan model $(p 1=0.019 \cdot p 2=0.099 . p 3=$ 185 0.331. $\left.R^{2}=0.99, P<0.01\right)$ ) describes the influence of temperature on the rate of 186 natural increase very well. The optimal temperature for population development, 187 calculated from the derivative Logan equation was $31.3^{\circ} \mathrm{C}$.

\section{Discussion}

189 Based on biological and ecological information published in the two last decades, the 190 immature developmental time of $B$. tabaci (from egg to adult) depends on the host 191 plant (Coudriet et al. 1985; Van Lenteren \& Noldus, 1990; Bethke et al., 1991; 192 Zalom et al., 1995; Tsai \& Wang, 1996; Muñiz \& Nombela, 1997; Nava-Camberos 193 et al., 2001) as well as on the whitefly populations or biotypes (Drost et al., 1998; 194 Muñiz, 2000; Muñiz \& Nombela, 2001). The developmental time of B. tabaci 
195 recorded at $25^{\circ} \mathrm{C}$ ranges from 17.3 to 22.8 days when reared on either aubergine,

196 tomato, sweet potato, cucumber, bean or pepper. The present results show that on

197 tomato, the population of Q-biotype B. tabaci newly introduced in southern France

198 require 25.6 days to complete development from egg to adult at $25^{\circ} \mathrm{C}$. In contrast,

199 Tsai \& Wang (1996) report a shorter developmental time (17.96 days) for a Floridian

200 B. argentifolii population on tomato (cultivar Suny Hybrid) at $25^{\circ} \mathrm{C}$. Based on the

201 model of Logan et al. (1976), the optimal temperature for the development of 202 immatures $\left(32.5^{\circ} \mathrm{C}\right)$ is higher than that calculated for Florida, Mississipi, and Arizona

203 populations of $B$. argentifolii $\left(29.9,28.2\right.$, and $30.0^{\circ} \mathrm{C}$, respectively) on aubergine

204 (Wang \& Tsai, 1996). The optimum for B. tabaci biotypes on all host plants tested

205 ranges from 30 to $33^{\circ} \mathrm{C}$ (Drost et al., 1998). The developmental threshold for

206 immatures belonging to the population studied here, estimated at $10.2^{\circ} \mathrm{C}$, is lower

207 than that reported in the literature, which ranges from $10.8^{\circ} \mathrm{C}$ (Von Arx et al., 1983)

208 to $12.5^{\circ} \mathrm{C}$ (Wang \& Tsai, 1996).

209 Based on the range of temperatures tested here, survival rates of immature stages of

210 B. tabaci from egg to adult are higher on the tomato cultivar Hilario than those

211 reported on other cultivars of tomato (Tsai \& Wang, 1996), Poinsettia (Enkegaard,

212 1993) and cotton (Wagner, 1995). Different responses to extreme temperatures, i.e.

213 in mortality of immatures, suggest that the Q-biotype population on tomato is more

214 tolerant to high temperatures $\left(>33^{\circ} \mathrm{C}\right)$ than diverse $B$. tabaci populations on

215 aubergine (Wang \& Tsai, 1996), cotton, and Poinsettia (Drost et al., 1998).

216 Fecundity of $B$. tabaci is generally highly variable and depends on temperature

217 (Enkegaard, 1993), host-plant species (Liu \& Oetting, 1994), and cultivar (Navon et

218 al., 1991). Thus, the total number of eggs laid at $25^{\circ} \mathrm{C}$ by a Q-biotype female reared

219 on tomato $c v$ Hilario (94.2 eggs) is considerably lower than that reported in the 
220 literature for females reared on aubergine (223.67) (Wang \& Tsai, 1996) and tomato

221 cv Suny Hybrid (165.55) (Tsai \& Wang, 1996).

222 Wang \& Tsai (1996) underline the importance of life table parameters to compare $B$.

223 tabaci populations and biotypes. On aubergine these authors (Wang \& Tsai, 1996)

224 find a high intrinsic rate of increase at $25^{\circ} \mathrm{C}(0.192), 27^{\circ} \mathrm{C}(0.191)$, and $30^{\circ} \mathrm{C}(0.169)$

225 compared with that found with the Q-biotype population on tomato at $25^{\circ} \mathrm{C}(0.106)$

226 and $30^{\circ} \mathrm{C}(0.123)$. However, at $35^{\circ} \mathrm{C}$, the net rate of increase of the B-biotype $(0.073)$

227 is lower than that of the French Q-biotype population (0.104). The tolerance to

228 extreme thermal conditions of the population newly introduced in France is also

229 confirmed by its shortest mean generation time recorded at $35^{\circ} \mathrm{C}$ ( 24.6 days).

230 The comparison between the results of this work and those from other studies (Wang

231 \& Tsai, 1996; Muñiz \& Nombela, 1996, 2001; Drost et al., 1998; Nombela et al., 232 2000, Muñiz, 2000) demonstrates clearly that the relationship between life-history

233 parameters and temperature is influenced highly by both insect biotype and host

234 plant species and variety. In spite of this high degree of variability within the Bemisia 235 complex, it is essential to better understand the population dynamics of the newly 236 introduced pest population in relation to temperature to improve control strategies 237 and evaluate its geographical extension capacity.

\section{References}

241 Arx, R. von, Baumgärtner, J. \& Delucchi, V. (1983) A model to simulate the population dynamics of Bemisia tabaci Genn (Homoptera: Aleyrodidae) on

243 cotton in the Sudan Gezira. Zeitschrift für Angewandte Entomologie, 96, 341244363. 
245 Bethke J.A., Paine, T.D. \& Nuessly, G.S. (1991) Comparative biology, morphometrics, and development of two populations of Bemisia tabaci (Homoptera: Aleyrodidae) on cotton and poinsettia. Annals of Entomological Society of America, 84, 407-411.

249 Chermitti, B., Braham, M., Alonso, C., Beitia, F. \& Cenis, J.L. (1997) Sur la 113.

Claridge, M.F., Dawah, H.A. \& Wilson, M.R. (1997) Species in insect herbivores and parasitoids - sibling species, host races and biotypes. Species, the Units of Biodiversity. (ed. by M.F., Claridge, H.A., Dawah, M.R.,Wilson), pp. 247-272. Chapman \& Hall, London.

Coudriet, D.L., Prabhaker, N., Kishaba, N. \& Meyerdirk, D.E. (1985) Variation in development rate on different hosts and overwintering of the sweetpotato whitefly Bemisia tabaci (Homoptera: Aleyrodidae). Environmental Entomology, 14, 516-519.

Curry, G.L. \& Feldman, R.M. (1987) Mathematical foundations of population dynamics. Texas A\& M University Press, College Station, 246 pp.

Dalmon, A., Cailly, M., Bouyer, S., Arnold-Gaulhiac, M., Cailly, A. \& Goarant, G. (2003) Emergence de virus transmis par aleurodes dans les cultures de tomate en France. Proceedings of the International Symposium on Greenhouse Tomato: Integrated Crop Protection and Organic Production, CTIFL, Paris, 24-29.

De Barro, P.J., Driver, F., Trueman, J.W.H. \& Curran, J. (2000) Phylogenic relationship of world populations of Bemisia tabaci (Gennadius) using ribosomal ITS1. Molecular Phylogenetics and Evolution, 16, 29-36. 
270 Demichelis, S., Bosco, D., Manino, A., Marian, D. \& Caciagli, P. (2000) Distribution of Bemisia tabaci (Hemiptera: Aleyrodidae) biotypes in Italy. Canadian Entomologist, 132, 519-527.

273 Drost, Y.C., van Lenteren, J.C. \& van Roermund, H.J.W. (1998) Life-history parameters of different biotypes of Bemisia tabaci (Hemiptera: Aleyrodidae) in relation to temperature and host plant: a selective review. Bulletin of Entomological Research, 88, 219-229.

Enkegaard, A. (1993) The poinsettia strain of the cotton whitefly, Bemisia tabaci (Homoptera: Aleyrodidae), biological and demographic parameters on poinsettia (Euphorbia pulcherima) in relation to temperature. Bulletin of Entomological Research, 83, 535-546.

Guirao, P., Beitia, F. \& Cenis, J.C. (1997) Biotype determination of Spanish populations of Bemisia tabaci (Hemiptera: Aleyrodidae). Bulletin of Entomological Research, 87, 587-593.

284 Horowitz, A.R., Denholm, I., Gorman, K., Cenis, J.L., Kontsedalov, S. \& Ishaaya, I. 285 (2003) Biotype Q of Bemisia tabaci identified in Israel. Phytoparasitica, 31, 9428698.

287 Hulting, F.L., Orr, D.B. \& Obrycki, J.J. (1990) A computer program for calculation 288 and statistical comparison of intrinsic rates of increase and associated life table parameters. Florida Entomologist, 73, 601-612.

290 Liu, T.X. \& Oetting, R.D. (1994) Oviposition preference of Bemisia tabaci 291 (Gennadius) on eight species of greenhouse-grown plants. Journal of Agricultural Entomology, 11, 177-179. 
Logan, J.A., Wollkind, D.J., Hoyt, S.C. \& Tanigoshi, L.K. (1976) An analytic model for description of temperature dependent rate phenomena in arthropods. Environmental Entomology, 5, 1133-1140.

Lopez-Avila, (1986) Natural ennemies. Bemisia tabaci - a literature survey on the Berks.

Meyer, J.S., Ingersoll, C.G., McDonald, L.L. \& Boyce, M S. (1986) Estimating

Monci, F., Navas-Castillo, J., Cenis, J.L., Lacasa, A., Benazoun, A. \& Moriones, E. (2000) Spread of tomato yellow leaf curl virus-Sar from the Mediterranean basin: presence in the Canary Islands and Morocco. Plant Disease, 84, 490

Muñiz, M. (2000) Host suitability of two biotypes of Bemisia tabaci on some common weeds. Entomologia Experimentalis et Applicata, 95, 63-70.

Muñiz, M. \& Nombela, G. (1997) Development, oviposition and female longevity of two biotypes of Bemisia tabaci (Homoptera: Aleyrodidae) on three varieties of Capsicum annuum L. IOBC/ WPRS Bulletin, 20, 143-146.

Muñiz, M. \& Nombela, G. (2001) Differential variation in development of the B- and

314 Naranjo, S.E. (2001) Conservation and evaluation of natural enemies in IPM systems for Bemisia tabaci. Crop Protection, 20, 835-852. 
316 Nava-Camberos, U., Riley, D.G. \& Harris, M.K. (2001) Temperature and host plant

317 effects on development, survival, and fecundity of Bemisia argentifolii

318 (Homoptera: Aleyrodidae). Environmental Entomology, 30, 55-63.

319 Navas-Castillo, J., Camero, R., Bueno, M. \& Moriones, E. (2000) Severe yellowing 320 outbreaks in tomato in Spain associated with infections of Tomato chlorosis 321 virus. Plant Disease, 84, 835-837.

322 Navon, A., Melamed, M.V., Zur, M. \& Ben, M.E. (1991) Effects of cotton cultivars 323 on feeding of Heliothis armigera and Spodoptera littoralis larvae and on 324 oviposition of Bemisia tabaci. Agriculture, Ecosystems and Environment, 35, $325 \quad 73-80$.

326 Oliviera, M.R.V., Henneberry, T.J. \& Anderson, P. (2001) History, current status, 327 and collaborative research projects for Bemisia tabaci. Crop Protection, 20, 709$328 \quad 723$.

329 Simón, B., Cenis, J.L., Demichelis, S., Rapisarda, C., Caciagli, P. \& Bosco, D. 330 (2003) Survey of Bemisia tabaci (Hemiptera: Aleyrodidae) biotypes in Italy with 331 the description of a new biotype (T) from Euphorbia characias. Bulletin of 332 Entomological Research, 93, 259-264.

333 Tsai, J.H. \& Wang, K. (1996) Development and reproduction of Bemisia argentifolii 334 on five host plants. Environmental Entomology, 25, 810-816.

335 Van Lenteren, J.C. \& Noldus, L.P.J.J. (1990) Whitefly-plant relationships: 336 behavorial and ecological aspects. Whiteflies: their bionomics, pest status and 337 management, (ed. by D Gerling), pp. 47-89. Intercept, Andover, Hampshire, 338 U.K. 
339 Wagner, T.L. (1995) Temperature-dependent development, mortality, and adult size

340 of sweetpotato whitefly biotype B (Homoptera: Aleyrodidae) on cotton.

$341 \quad$ Environmental Entomology, 24, 1179-1188.

342 Wang, K. \& Tsai, J.H. (1996) Development and reproduction of Bemisia argentifolii

343 (Homoptera: Aleyrodidae) on five host plants. Annals of Entomological Society

$344 \quad$ of America, 89, 375-384.

345 Zalom, F.G., Castañe, C. \& Gabarra, R. (1995) Selection of some winter-spring 346 vegetable crop hosts by Bemisia tabaci (Homoptera: Aleyrodidae). Journal of $347 \quad$ Economic Entomology, 88, 70-76.

348 
Table 1. Developmental period (day \pm SE) of immature stages of Bemisia tabaci (Q biotype) at 5 constant temperatures.

\begin{tabular}{|c|c|c|c|c|c|c|c|}
\hline \multirow{2}{*}{$\begin{array}{l}\text { Temp. } \\
\left({ }^{\circ} \mathrm{C}\right)\end{array}$} & & \multicolumn{6}{|c|}{ Stages } \\
\hline & $n$ & eggs & instar 1 & instar 2 & instar 3 & instar 4 & $\begin{array}{c}\text { From egg to } \\
\text { adult }\end{array}$ \\
\hline 17 & 80 & $21.5 \pm 0.09 a$ & $9.4 \pm 0.35 a$ & $7.5 \pm 0.93 a$ & $8.0 \pm 0.42 \mathrm{a}$ & $9.4 \pm 0.33 \mathrm{a}$ & $55.8 \pm 0.47 a$ \\
\hline 21 & 80 & $14.0 \pm 0.09 b$ & $7.1 \pm 0.21 b$ & $4.1 \pm 0.18 b$ & $8.8 \pm 0.23 a$ & $5.6 \pm 0.18 b$ & $39.6 \pm 0.69 b$ \\
\hline 25 & 80 & $10.4 \pm 0.13 c$ & $4.3 \pm 0.19 c$ & $3.7 \pm 0.16 b c$ & $3.8 \pm 0.15 b$ & $3.4 \pm 0.12 \mathrm{c}$ & $25.6 \pm 0.26 c$ \\
\hline 30 & 80 & $7.7 \pm 0.06 \mathrm{~d}$ & $3.2 \pm 0.13 \mathrm{~d}$ & $3.3 \pm 0.15 c$ & $3.5 \pm 0.15 b$ & $2.5 \pm 0.09 \mathrm{~d}$ & $20.2 \pm 0.24 d$ \\
\hline 35 & 38 & $6.5 \pm 0.10 \mathrm{e}$ & $3.9 \pm 0.17 \mathrm{~cd}$ & $3.3 \pm 0.21 \mathrm{c}$ & $3.5 \pm 0.29 b$ & $3.3 \pm 0.22 \mathrm{c}$ & $20.5 \pm 0.33 d$ \\
\hline
\end{tabular}

Within columns means followed by the same letters are not significantly different $(\mathrm{P}>0.05)$. 
Table 2. Survivorship (percentage) of immature stages of Bemisia tabaci (Q biotype) at 5 constant temperatures.

\begin{tabular}{ccccccccc}
\hline \hline & \multicolumn{8}{c}{ Stages } \\
\cline { 2 - 8 } Temp. $\left({ }^{\circ} \mathrm{C}\right)$ & $\begin{array}{c}n \\
\text { eggs }\end{array}$ & egg & instar 1 & instar 2 & instar 3 & instar 4 & $\begin{array}{c}n \\
\text { adults }\end{array}$ & $\begin{array}{c}\text { From egg to } \\
\text { adult }\end{array}$ \\
\hline 17 & 80 & 91.3 & 84.9 & 96.8 & 73.3 & 63.6 & 38 & $48 \mathrm{c}$ \\
21 & 80 & 98.7 & 98.7 & 93.4 & 93.0 & 97.0 & 64 & $83 \mathrm{a}$ \\
25 & 80 & 100 & 93.8 & 94.7 & 98.6 & 97.1 & 68 & $85 \mathrm{a}$ \\
30 & 80 & 100 & 95.0 & 96.1 & 93.2 & 97.1 & 66 & $82 \mathrm{a}$ \\
35 & 38 & 100 & 97.4 & 89.2 & 78.8 & 92.3 & 24 & $63 \mathrm{~b}$ \\
\hline
\end{tabular}

Within columns means followed by the same letters are not significantly different $(\mathrm{P}>0.05)$. 
Table 3. Fecundity (number of eggs per female \pm SE) and longevity (days \pm SE) of Bemisia tabaci (Q biotype) at 5 constant temperatures.

\begin{tabular}{cccc}
\multirow{2}{*}{ Temp. $\left({ }^{\circ} \mathrm{C}\right)$} & \multicolumn{3}{c}{} \\
\cline { 2 - 4 } & $n$ & Total fecundity & Longevity \\
\hline 17 & 30 & $49.3 \pm 6.7 \mathrm{~b}$ & $39.6 \pm 3.6 \mathrm{a}$ \\
21 & 30 & $105.3 \pm 10.4 \mathrm{a}$ & $27.3 \pm 0.8 \mathrm{~b}$ \\
25 & 30 & $94.2 \pm 12.3 \mathrm{a}$ & $21.9 \pm 1.7 \mathrm{c}$ \\
30 & 30 & $58.6 \pm 10.4 \mathrm{~b}$ & $14.6 \pm 1.1 \mathrm{~d}$ \\
35 & 30 & $41.0 \pm 5.6 \mathrm{~b}$ & $8.5 \pm 0.7 \mathrm{e}$ \\
\hline
\end{tabular}

$\overline{\text { Within columns means followed by the same letters are not significantly different }(\mathrm{P}>0.05)}$. 
Table 4. Comparison of life table parameters of Bemisia tabaci (Q biotype) at 5 constant temperatures. $\mathrm{n}=$ number of females. $\mathrm{r}_{\mathrm{m}}=$ Jacknife estimate of the intrinsic rate of increase. $\mathrm{CI}=$ confidence interval estimate of $\mathrm{r}_{\mathrm{m}}$. Ro $=$ net reproductive rate (Standar error). $\mathrm{G}=$ mean generation time in day. $\lambda=$ finite rate of increase $=\exp \left(\mathrm{r}_{\mathrm{m}}\right)$.

\begin{tabular}{ccccccc}
\hline \hline \multirow{2}{*}{$\begin{array}{c}\text { Temp. } \\
\left({ }^{\circ} \mathrm{C}\right)\end{array}$} & $n$ & $\mathrm{r}_{\mathrm{m}}$ & $95 \% \mathrm{CI}$ & Ro & $\mathrm{G}$ & $\lambda$ \\
\cline { 2 - 7 } & 30 & $0.045 \mathrm{c}$ & $0.044-0.046$ & $29.8(0.2)$ & 77.2 & 1.05 \\
17 & 24 & $0.079 \mathrm{~b}$ & $0.078-0.080$ & $52.5(0.1)$ & 49.9 & 1.08 \\
21 & 18 & $0.106 \mathrm{a}$ & $0.090-0.121$ & $39.5(5.5)$ & 35.1 & 1.11 \\
25 & 24 & $0.123 \mathrm{a}$ & $0.103-0.142$ & $23.6(4.3)$ & 26.5 & 1.13 \\
30 & 23 & $0.104 \mathrm{a}$ & $0.087-0.119$ & $12.3(1.8)$ & 24.6 & 1.11 \\
35 & & &
\end{tabular}

Within columns means followed by the same letters are not significantly different $(\mathrm{P}>0.05)$. 


\section{Figure captions}

Fig. 1. Influence of temperature on development time of Bemisia tabaci (Q biotype). Points: experimental values. curve simulated by Logan et al. (1976).

Fig. 2. Influence of temperature on survivorship of Bemisia tabaci (Q biotype). Points: experimental values. curve simulated by Curry \& Feldman model (1987)

Fig. 3. Influence of temperature on female longevity of Bemisia tabaci (Q biotype). Points: experimental values. curve simulated by exponential model.

Fig. 4. Influence of temperature on fecundity of Bemisia tabaci (Q biotype). Points: experimental values. curve simulated by multiplicative exponential model.

Fig. 5. Influence of temperature on intrinsic rate of increase of Bemisia tabaci (Q biotype). Points: experimental values. curve: simulated by Logan et al. (1976) model. 
Fig. 1.

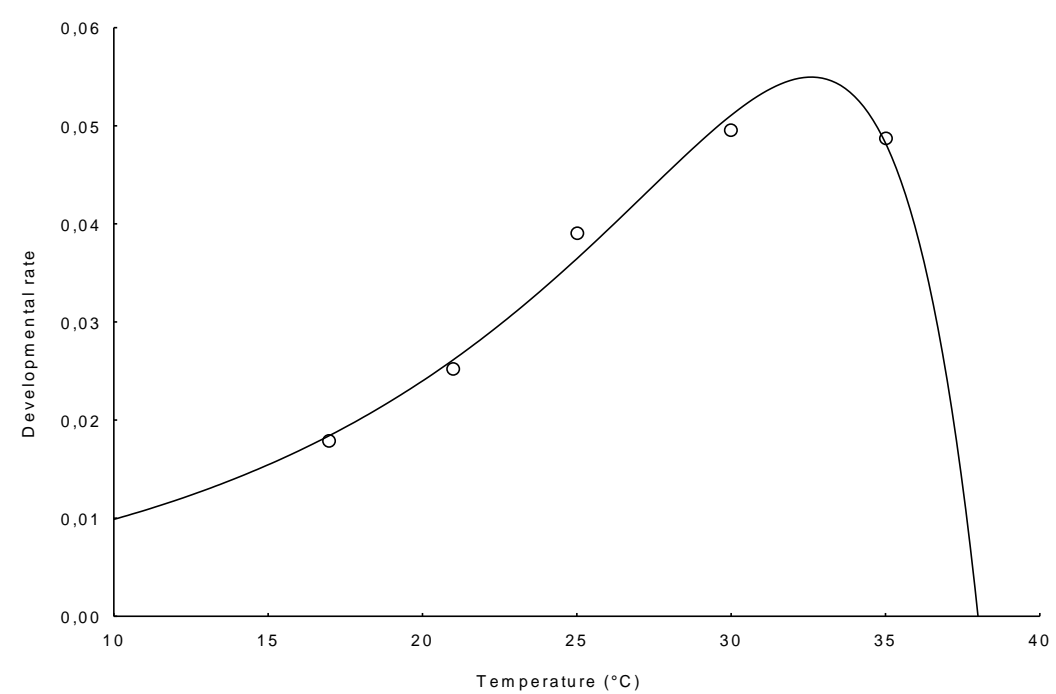


Fig. 2.

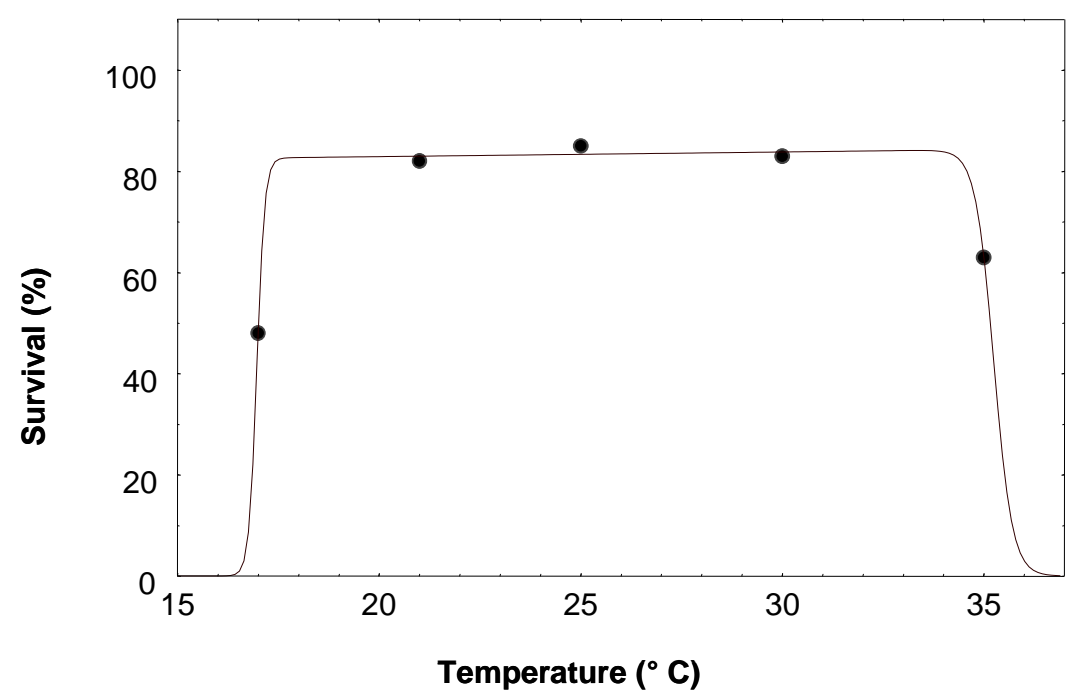


Fig. 3

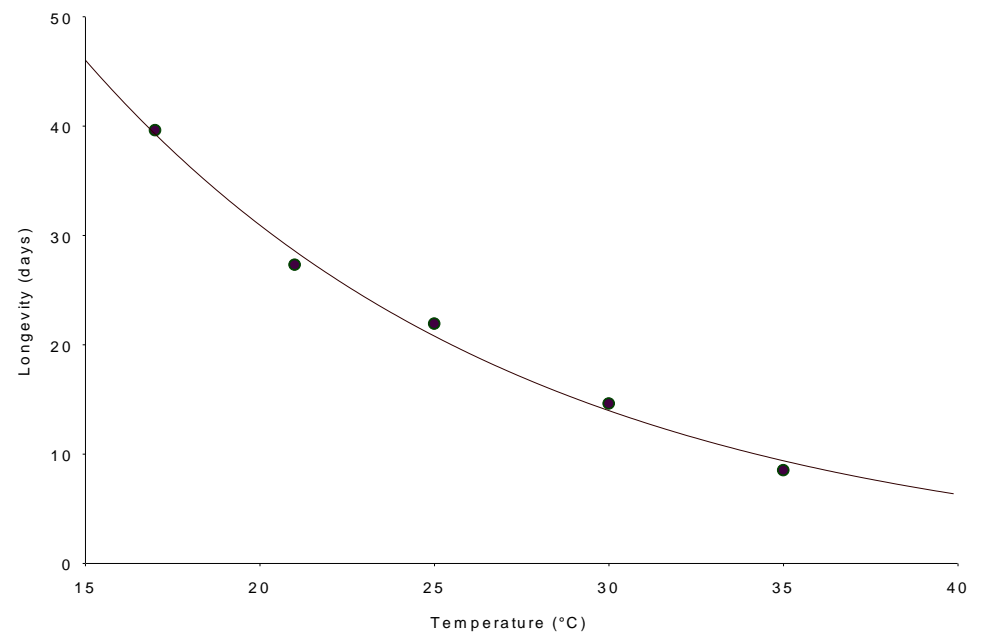


Fig. 4.

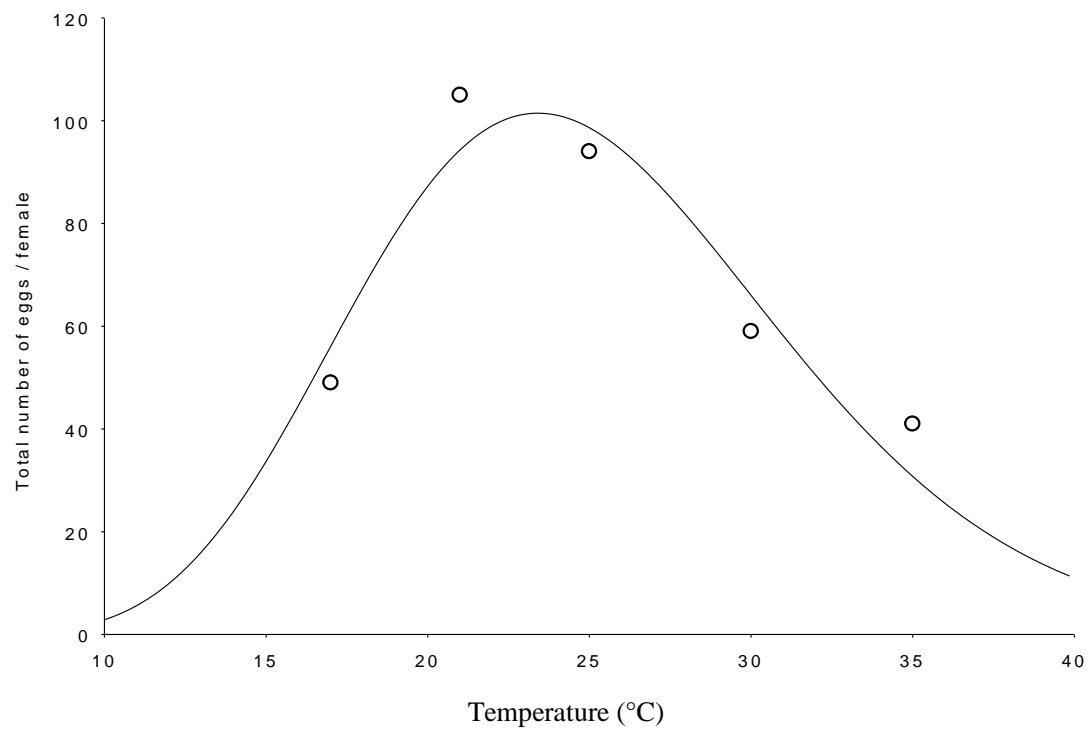


Fig. 5.

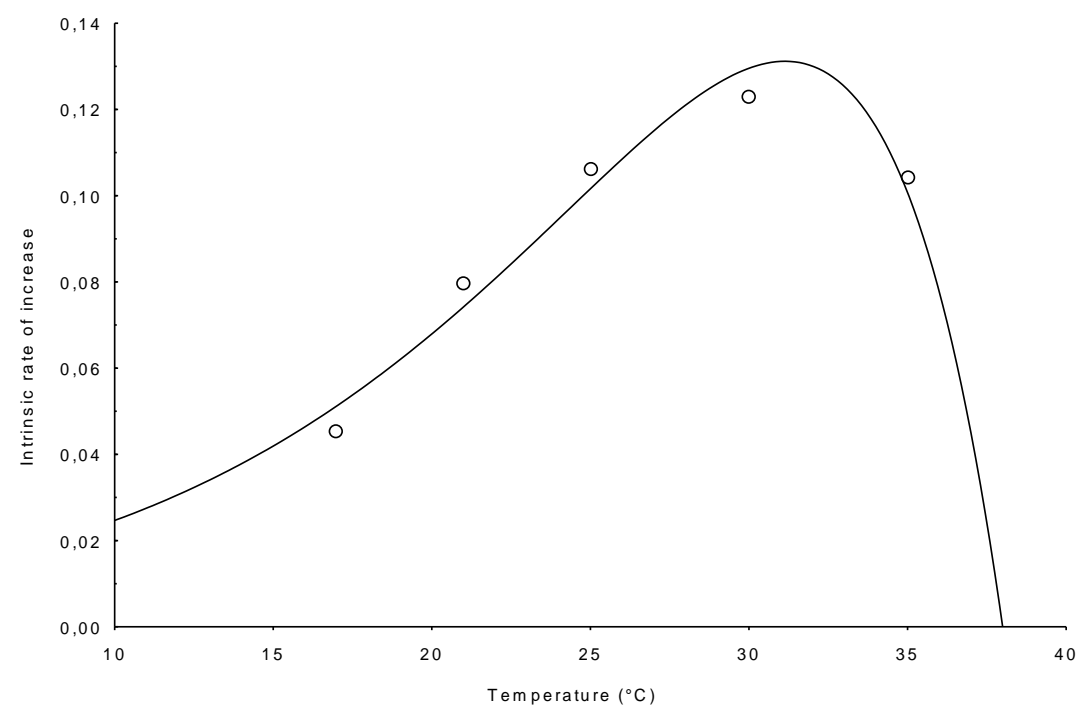

